\title{
TEACHERS ENGAGEMENT GURU MADRASAH ALIYAH DALAM PEMBELAJARAN DI MASA PANDEMI COVID-19 (Teachers Engagement of Madrasah Aliyah's Teachers In Learning During Covid-19)
}

\author{
Aji Sofanudin \\ Balai Penelitian dan Pengembangan Agama Semarang \\ ajisofan@gmail.com
}

\author{
Rahmawati Prihastuty \\ Fakultas Ilmu Pendidikan UNNES \\ rahmawati.prihastuty@mail.unnes.ac.id
}

\author{
Ayon Diniyanto \\ Institut Agama Islam Negeri (IAIN) Pekalongan \\ Ayondiniyanto24@gmail.com
}

\begin{abstract}
Abstrak
Pandemi covid-19 telah memaksa semua aspek kehidupan berubah, termasuk pembelajaran di madrasah aliyah. Penelitian ini bertujuan untuk mengetahui perbedaan teacher engagement guru dilihat dari jenis kelamin dan status sertifikasi guru madrasah aliyah di kabupaten Tegal. Penelitian ini menggunakan mix method dengan subjek penelitian sebanyak 302 guru madrasah aliyah. Temuan penelitian menunjukkan bahwa teacher engagement terdiri atas lima aspek yaitu vigor, dedication, absorpsion, job satisfaction, dan quitting intention. Dengan menggunakan lima aspek tersebut, diketahui bahwa ada perbedaan teacher engagement antara guru laki-laki dan perempuan. Guru laki-laki memiliki nilai teacher engagement lebih tinggi daripada guru perempuan. Mean teacher engagement guru laki-laki sebesar 4,62 sementara guru perempuan sebesar 4,55. Nilai $r_{h}$ sebesar 0,209 lebih besar daripada nilai $r_{\text {tabel }}$ baik pada signifikansi 5\% ataupun $1 \%$. Ini menunjukkan bahwa ada perbedaan nilai teacher engagement antara laki-laki dan perempuan. Sementara mean guru yang sudah tersertifikasi $(4,73)$ lebih tinggi daripada guru belum tersertifikasi (4,48). Nilai $r_{h}$ sebesar -0,001 menunjukkan bahwa tidak ada perbedaan nilai teacher engagement antara guru sertifikasi dengan guru belum tersertifikasi pada Madrasah Aliyah di Kabupaten Tegal. Temuan ini perlu mendapatkan perhatian dari pengambil kebijakan di Kantor Kementerian Agama Provinsi Jawa Tengah.
\end{abstract}

Kata Kunci: Teacher Engagement, Madrasah Aliyah, Sertifikasi

\begin{abstract}
The Covid-19 pandemic has forced all aspects of life to change, including learning at Madrasah Aliyah. This study aims to determine the differences of teacher engagement from gender perspective and certification status of teachers in Madrasah Aliyah at Tegal regency. This study used a mixed method with 302 research participants of teachers at Madrasah Aliyah. The research findings show that teachers' engagement consists of five aspects, namely vigor, dedication, absorption, job satisfaction, and quitting intention. By using these five aspects, it is known that there are differences in teacher engagement between male and female teachers. Male teachers have higher teacher engagement scores than female teachers. Mean teacher engagement for male teachers was 4.62
\end{abstract}


while female teachers were 4.55. $r_{h}$ value is 0.209 , it is greater than the value of $r_{\text {tabel }}$ at either $5 \%$ or $1 \%$ significance. This shows that there are differences in the value of teacher engagement between men and women. Meanwhile, the mean of teachers who were certified (4.73) was higher than uncertified teachers (4.48). The $r_{h}$ value of -0.001 indicates that there is no difference in the value of teacher engagement between certified and uncertified teachers in Madrasah Aliyah at Tegal regency. This finding deserves attention from policy makers at the Ministry of Religious Office of Central Java Province.

Keyword: Teacher Engagement, Madrasah Aliyah, Certification

\section{PENDAHULUAN}

Pandemi Covid-19 telah memaksa semua berubah tak terkecuali guru madrasah. Pembelajaran daring menjadi fenomena yang tidak bisa dihindari bagi dunia pendidikan. Kebijakan bersama Kemendikbud, Kemenag, Kemenkes, dan Gugus Tugas bahwa hanya di daerah hijau (sebesar $6 \%$ ) yang bisa menyelenggarakan pendidikan luring (tatap muka). Sebanyak $94 \%$ pembelajaran akan dilakukan secara daring ${ }^{1}$. Regulasi ini kemudian direvisi dengan memperluas daerah yang bisa melakukan KBM secara tatap muka (7/8/2020). Selain zona hijau, zona kuning pun diperkenankan melakukan tata muka. Berdasarkan data yang dilansir pemerintah, jumlah peserta didik di zona merah dan oranye 57 persen di $238 \mathrm{kab} / \mathrm{kota}$, sementara jumlah peserta didik di zona hijau dan kuning sebanyak 43 persen di $276 \mathrm{kab} / \mathrm{kota}^{2}$. Mayoritas siswa melakukan pembelajaran daring atau belajar dari rumah.

Kondisi ini memaksa semua elemen pendidikan terutama siswa, guru, dan TU untuk berubah melakukan adaptasi. Guru dituntut untuk meningkatkan berbagai kompetensinya: kompetensi professional, pedagogik, kepribadian dan sosial menghadapi perubahan tersebut. Kompetensi pedagogik terutama indikator penguasaan terhadap IT (pemanfaatan teknologi pembelajaran) perlu ditingkatkan. Demikian juga kompetensi yang lain. Siswa juga dituntut terbiasa melakukan pembelajaran daring.

Banyak guru mengeluh karena kesulitan melakukan pembelajaran. Pembelajaran biasa tidak boleh sementara pembelajaran daring dia tidak memiliki kemampuan untuk melaksanakan. Riset sebelumnya banyak berbicara tentang problem pembelajaran daring di sekolah/madrasah. Beberapa problem yang muncul misalnya: kendala jaringan internet, minimnya kuota, tidak punya $\mathrm{hp} /$ computer, rendahnya kapasitas $\mathrm{SDM}^{3}$. Demikian juga puslitbang Pendidikan agama dan keagaman sebanyak $80 \%$ pembelajaran dengan penugasan ${ }^{4}$. Ini artinya SDM guru dipertanyakan. Padahal problem tersebut tidak akan muncul manakala ada komitmen yang tinggi dari guru. Kajian ini tentang komitmen, dedikasi, dan keterlitbaan guru dalam peningkatan mutu pendidikan sangat minim. Padahal ini merupakan bagian dari kompetensi kepribadian yang harus dimiliki oleh guru. Penelitian tentang guru banyak didominasi kajian tentang kompetensi professional dan pedagogik dari seorang guru. Salah satu hal yang penting diketahui adalah terkait teacher engagement di

\footnotetext{
${ }^{1}$ Siaran Pers Kementerian Pendidikan dan Kebudayaan, 15 Juni 2020

${ }^{2}$ Cecep Darmawan "Kedaulatan Digital" Opini Republika, 3 September 2020

3 Iswanto, A., dkk, "Survei Pembelajaran Jarak Jauh Masa Covid" Balai Penelitian dan Pengembangan Agama Semarang, 2020

${ }^{4}$ Murtadlo, dkk. "Survei Pembelajaran Jarak Jauh" Puslitbang Pendidikan Agama dan Keagamaan, 2020
} 
madrasah. Karakteristik madrasah berbeda dengan sekolah terutama pada penambahan jumlah jam pelajaran agama. Data emis menyebutkan bahwa kabupaten Tegal merupakan salah satu basis madrasah. Jumlah satuan pendidikan sebanyak sebanyak 17 lembaga.

Riset terkait pembelajaran jarak jauh (PJJ) di masa pandemi lebih banyak mengulas tentang praktik dan problem pembelajaran yang ada dalam PJJ ${ }^{5}$. Riset PJJ lebih banyak mengupas tentang tidak optimalnya hasil belajar siswa dan kesulitan siswa memahami materi pembelajaran ${ }^{6}$. Penelitian ini berbeda dengan penelitian sebelumnya yakni melihat dari sisi guru, terutama guru madrasah aliyah. Bagaimana guru merasa engaged dalam pembelajaran. Bagaimana guru memiliki vigor, dedication, absorpsion, job satisfaction, dan quitting intention dalam menjalankan tugas sebagai guru. Keterlibatan guru secara total tentu akan mempengaruhi kualitas pembelajaran pada umumnya. Secara operasional penelitian ini bertujuan untuk mengetahui teachers engagement guru Madrasah Aliyah di kabupaten Tegal menggunakan teori teachers engagement at work yang dikembangkan oleh Klassen dkk. ${ }^{7} 8$. Secara khusus penelitian ini bertujuan untuk mengetahui (1) nilai teachers engagement guru madrasah aliyah di kabupaten Tegal, (2) perbedaan nilai teachers engagement guru madrasah aliyah dilihat dari jenis kelamin, (3) perbedaan nilai teachers engagement guru madrasah aliyah dilihat dari status sertifikasi

Secara nasional jumlah madrasah sebanyak 82.418 lembaga terdiri atas 4.010 lembaga berstatus negeri dan 78.408 berstatus swasta. http://emisdep.kemenag.go.id/madrasah_emis/ dashboard/index.php?content=data-statistik. Ini berarti bahwa hanya 4,9 \% madrasah (pada semua tingkatan) berstatus negeri. Sebanyak 95,1\% merupakan madrasah berstatus swasta. Sebagian besar madrasah sesungguhnya adalah milik masyarakat. Oleh karena itu, pengembangan madrasah seharusnya berbasis pada masyarakat. Rasa kepemilikan masyarakat terhadap madrasah tinggi. Mestinya demikian juga rasa kepemilikan guru terhadap madrasah tinggi. Inilah yang disebut dengan teacher engagement yaitu vigor, dedikasi, absorpsi, job satisfaction, dan quitting intention. Teacher engagement penting diketahui sebagai ukuran kompetensi kepribadian seorang guru. Guru swasta, apalagi owner madrasah bisa jadi memiliki teacher engagement yang lebih tinggi dibandingkan dengan guru negeri. Meskipun dengan berbagai keterbatasan, guru swasta lebih memiliki jiwa-memiliki madrasah dibandingkan dengan guru negeri. Oleh karena itu, hendaknya pemerintah memberikan penghargaan setidaknya memperhatikan kesejahteraan para guru swasta. Semua guru swasta hendaknya mendapatkan tunjangan sertifikasi.

\section{METODE PENELITIAN}

Penelitian ini menggunakan pendekatan kuantitatif. Angket diadopsi dari penelitian tentang teacher engagement at work dari Klassen dkk. Ada lima aspek teacher engagement yang merupakan pengembangan dari UWES (Utrecht Work Engagement Scale) kemudian disesuaikan dengan konteks guru madrasah dan pandemi Covid-19. Angket berisi lima aspek yaitu (1) vigor, (2)

5 Iswanto, Agus dkk, "Survei Pembelajaran Jarak Jauh Masa Covid" Balai Penelitian dan Pengembangan Agama Semarang, 2020.

${ }^{6}$ Noor Amirudin, 'Problematika Pembelajaran Pendidikan Agama Islam Di Era Digital', Prosiding Seminar Nasional PAI Dengan Pendekatan Multidisipliner, 2019.

${ }^{7}$ Robert M. Klassen and others, 'Teachers Engagement at Work: An International Validation Study', Journal of Experimental Education, 2012 <https://doi.org/10.1080/00220973.2012.678409>.

${ }^{8}$ Robert M. Klassen, Sündüs Yerdelen, and Tracy L Durksen, 'Measuring Teacher Engagement: Development of the Engaged Teachers Scale (ETS)', Frontline Learning Research, 2013 <https://doi.org/10.14786/flr.v1i2.44>. 
dedication, (3) absorpsion, (4) job satisfaction, dan (5) quitting intention. Dari lima aspek tersebut kemudian dibuat indikator dengan 15 item pertanyaan tertutup dan tiga pertanyaan terbuka.

Tabel 1 Aspek dan Indikator Teachers Engagement

\begin{tabular}{llll}
\hline No & Aspek & Indikator & Butir \\
\hline 1 & Vigor & Semangat, pantang menyerah & $1,2,3$ \\
\hline 2 & Dedication & $\begin{array}{l}\text { Bangga, antusias, memberi } \\
\text { inspirasi }\end{array}$ & $4,5,6$ \\
\hline 3 & Absorpsion & $\begin{array}{l}\text { Sungguh-sungguh, menikmati } \\
\text { pekerjaan, senang meski } \\
\text { kondisi susah }\end{array}$ & \\
& & $\begin{array}{l}\text { Puas bekerja, senang bekerja, } \\
\text { komitmen tinggi }\end{array}$ & $10,11,12$ \\
\hline 4 & Job satisfaction & ketidakbetahan kerja & $13,14,15$ \\
\hline 5 & Quitting intention &
\end{tabular}

Sumber: diadopsi dari Klassen, dkk

Dari tabel 1 kemudian dibuat item pertanyaan sebagai berikut:

Tabel 2 Item Pertanyaan

\begin{tabular}{lllll}
\hline No & Pertanyaan & SL & KD & J \\
\hline 1 & Saya tetap bersemangat mengajar di masa pandemi covid-19 & & \\
\hline 2 & $\begin{array}{l}\text { Saya berusaha mempelajari aplikasi IT untuk kelancaran } \\
\text { pembelajaran daring di masa pandemi covid-19 }\end{array}$ \\
\hline 3 & $\begin{array}{l}\text { Saya berusaha menerapkan berbagai metode pembelajaran } \\
\text { pada masa pandemi covid-19 }\end{array}$ \\
\hline 4 & Saya bangga menjadi guru madrasah \\
\hline 5 & $\begin{array}{l}\text { Saya tetap antusias mengajar meskipun pembelajaran } \\
\text { dilakukan secara daring }\end{array}$ \\
\hline 6 & $\begin{array}{l}\text { Pembelajaran yang saya lakukan pada masa pandemi covid-19 } \\
\text { menginspirasi siswa untuk tetap semangat belajar }\end{array}$ \\
\hline 7 & $\begin{array}{l}\text { Saya bersungguh-sungguh mengajar pada masa pandemi } \\
\text { covid-19 }\end{array}$ \\
\hline 8 & Saya menikmati tugas mengajar pada masa pandemi covid-19 \\
\hline 9 & $\begin{array}{l}\text { Saya tetap senang mengajar meskipun dengan berbagai } \\
\text { keterbatasan pada masa pandemi covid-19 }\end{array}$ \\
\hline 10 & $\begin{array}{l}\text { Saya puas dengan apa yang saya peroleh sebagai guru } \\
\text { madrasah }\end{array}$ \\
\hline 11 & Saya merasa senang bekerja sebagai guru madrasah \\
\hline 12 & Saya berkomitmen menjalankan tugas sebagai guru madrasah \\
\hline 13 & $\begin{array}{l}\text { Saya berpikir untuk berhenti menjadi guru madrasah di tempat } \\
\text { saya bekerja* }\end{array}$ \\
\hline 14 & Saya bermaksud untuk berhenti dari profesi guru madrasah* \\
\hline 15 & Saya berharap untuk pindah ke profesi/pekerjaan lain* \\
\hline
\end{tabular}

NB: SL=selalu, $\mathrm{S}=$ sering, $\mathrm{KD}=$ kadang-kadang, $\mathrm{J}=$ jarang, $\mathrm{TP}=$ tidak pernah. Khusus Item pertanyaan no 10 menggunakan terminologi pilihan yang berbeda (sangat puas, puas, kadang-kadang, jarang, tidak pernah). Item pertanyaan no 13, 14, dan 15 bersifat unfovourable. Selain itu, ditambahkan tiga pertanyaan terbuka yaitu terkait: kendala pembelajaran daring, cara mengatasi kendala tersebut, dan harapan terhadap pemerintah cq kementerian agama. 
Pengumpulan data dilakukan dengan observasi, wawancara, telaah dokumen, dan angket dengan memanfaatkan aplikasi google form. Observasi dilakukan di kantor Kementerian Agama Kabupaten Tegal, seksi pendidikan madrasah dan Madrasah Aliyah Negeri 1 Kabupaten Tegal dan MA Ma'hathut Tholabah. Wawancara dilakukan terhadap kasi pendma, ketua pokjawas, pengawas madrasah aliyah, kepala madrasah dan guru madrasah.

Telaah dokumen untuk mengetahui data kelembagaan madrasah aliyah dan data guru madrasah aliyah di kabupaten Tegal. Kelembagaan madrasah Aliyah berjumlah 17 lembaga. Sementara jumlah guru yang terdapat di kantor kementerian agama Kabupaten Tegal berjumlah 350 orang. Berikut ini adalah data kelembagaan MA yang ada di Kabupaten Tegal

Tabel 3 Data Kelembagaan MA di Kabupaten Tegal

\begin{tabular}{llll}
\hline No & Nama Lembaga & Alamat & Akreditasi \\
\hline 1 & MAN 1 Tegal & Jl Ponpes Babakan Jatimulya & A \\
\hline 2 & MAN 2 Tegal & Jl Gampit No 1 Pagerbarang & B \\
\hline 4 & MAS Al-Iman & Jl. Raya II Tegal Slawi & B \\
\hline 5 & MAS Raudlotut Tholibin & $\begin{array}{l}\text { Jl. Raya Banjaran-Balamoa Km. 03 Desa } \\
\text { Kalikangkung Rt.01/rw.02 }\end{array}$ & B \\
\hline 6 & MAS Al Ikhlas & Jl. KH. Maarif & B \\
\hline 7 & MAS Ma`hadut Tholabah & Jln. Pondok Pesantren Babakan & B \\
\hline 8 & MAS Darussalam & $\begin{array}{l}\text { Jl. Raya Kalibakung-Banjaranyar No. 10 } \\
\text { Rt 05 Rw 02 }\end{array}$ & C \\
\hline 9 & MAS Al Ittihad & $\begin{array}{l}\text { Jalan Jurusan Jatibarang Balapulang } \\
\text { Wetan Rt 05 Rw 10 }\end{array}$ & B \\
\hline 10 & MAS Al Islamiyah & $\begin{array}{l}\text { Jl. Ki Gede Sebayu Rt 04 Rw 04 Desa } \\
\text { Danawarih }\end{array}$ & C \\
\hline 11 & $\begin{array}{l}\text { MAS NU Miftahul Ulum } \\
\text { Margasari }\end{array}$ & Jl. Masjid Karangjati - Margasari & C \\
\hline 12 & MAS Asy-Syafi iyah & Jl. Raya Karangasem Rt/rw 01/01 & B \\
\hline 13 & MAS Darul Mujahadah & Jl. Pesantren No.01 & B \\
\hline 14 & MAS Al Madinah & Jl. Kajenengan 26 Tegalkubur & C \\
\hline 15 & $\begin{array}{l}\text { MUHAMMADIYAH } \\
\text { AHMAD DAHLAN }\end{array}$ & Jl. Raya Banjaranyar Kalibakung Km 2 & C \\
\hline 16 & MAS Al Muzzammil & Jl Raya Banjarnyar Rt 06 Rw 05 & Blm \\
\hline 17 & $\begin{array}{l}\text { MAS Tarbiyatut Tholibin } \\
\text { Bumijawa }\end{array}$ & Jl Raya Bumi Jawa & Blm \\
\hline
\end{tabular}

Penyebaran angket dilakukan dengan tiga cara jalur: (1) jalur struktural melalui Kasi Pendma Kantor Kementerian Agama Kabupaten Tegal, (2) jalur fungsional yakni pengawas madrasah aliyah dan (3) jalur kolega/teman sejawat yakni kepala dan guru madrasah aliyah. Populasi dalam penelitian ini adalah seluruh guru madrasah aliyah yang ada di kabupaten yakni sebanyak 350 guru. Pengumpulan data angket (melalui googleform) dilakukan selama 10 hari yaitu tanggal 15 Juli s.d 25 Juli 2020. Angket diadapati dari teori UWES tentang work engagement dan Kisman tentang teacher engagement yang kemudian dikaitkan dengan konteks madrasah dan pandemi covid-19.

Analisis data yang digunakan dalam penelitian ini diolah dengan bantuan software SPSS versi 21. Data angket penelitian diperoleh dengan memanfaatkan googleform. Uji statistik yang 
didapatkan melalui bantuan software SPSS 21 berupa analisis deskriptif yang dapat mengungkap trait dari subjek dalam penelitian ini.

\section{PEMBAHASAN}

Data emis menyebutkan bahwa secara kelembagaan madrasah aliyah di Kabupaten Tegal berjumlah 17 lembaga. Dari data tersebut sebanyak dua lembaga berstatus negeri (MAN) dan 15 lembaga adalah swasta (MAS). Sementara jumlah guru madrasah aliyah di Kabupaten Tegal sebanyak 350 guru (data seksi pendma, Kemeneg Kab Tegal 2020). Mayoritas guru berstatus sebagai guru swasta (non PNS). Magnet madrasah aliyah berada di MAN 1 Kabupaten Tegal yang merupakan madrasah aliyah tertua di Jawa Tengah. Dari sisi jumlah siswa/PPDB yang terbanyak adalah MAN 1 Tegal (menolak murid/ada seleksi). Madrasah lain tidak ada, semua pendaftar masuk. Dari sisi pengelolaan ada madrasah aliyah mandiri (berdiri sendiri), kompleks (memiliki MI, MTs, MA) dan berada di lingkungan pesantren. Secara umum, madrasah aliyah yang berada di lingkungan pesantren memiliki jumlah siswa yang lebih banyak dibandingkan dengan madrasah yang lain.

Data guru madrasah Aliyah di Kabupaten Tegal sebanyak 350 guru, ini sekaligus menjadi populasi dalam penelitian ini. Adapun sampel yang digunakan masuk sebanyak 311 guru. Data yang diolah berjumlah 302 angket karena ada beberapa data yang rusak, double, dan tidak lengkap dalam pengisian. Data di kemenag menyebutkan bahwa sebanyak 155 guru sudah sertifikasi. Sementara sebanyak 195 guru madrasah aliyah belum tersertifikasi.

Karakteristik madrasah tidaklah tunggal. Dilihat dari pengelolaan ada beberapa ragam Madrasah: (1) madrasah tunggal, (2) madrasah kompleks, (3) madrasah berbasis pesantren, dan (4) madrasah plus RA/TK. Dilihat dari status ada negeri ada swasta. Dilihat dari Yayasan penyelenggara ada berbagai macam. Dilihat dari akreditasi: A, B, C, dan belum terakreditasi. Dilihat dari jenjang dikenal MI, MTs, dan MA ${ }^{9}$. Kondisi ini juga terjadi pada madrasah di kabupaten Tegal yang memiliki karakteristik beragam. Secara umum, madrasah berbasis pesantren memiliki jumlah peserta didik lebih banyak dibandingkan dengan tipe madrasah yang lain. MAN 1 Kabupaten Tegal merupakan madrasah yang paling diminati di kabupaten Tegal. Meskipun berstatus sebagai madrasah negeri tetapi sejatinya madrasah tersebut berbasis pesantren. Madrasah ini berasal dari madrasah swasta yang kemudian dinegerikan. Lokasi madrasah ini juga berada di lingkungan pesantren.

Tabel 4 Jumlah Madrasah Aliyah di Tegal

\begin{tabular}{lllll}
\hline \multirow{2}{*}{ No } & Madrasah & Jumlah & & \\
\cline { 3 - 5 } & & Negeri & Swasta & Jumlah \\
\hline 1 & Madrasah Ibtidaiyah & 3 & 176 & 179 \\
\hline 2 & Madrasah Tsanawiyah & 5 & 72 & 77 \\
\hline 3 & Madrasah Aliyah & 2 & 14 & 16 \\
\hline Jumlah & 10 & 262 & 272 \\
\hline Sumber:
\end{tabular}

Sumber: Data Emis 2020

Nilai teacher engagement diperoleh dari data angket yang diisi oleh guru madrasah aliyah. Dengan bantuan dari seksi pendidikan madrasah dan pengawas MA di Kabupaten Tegal hampir seluruh guru madrasah aliyah mengisi angket yang disebarkan (15 Juli s.d 25 Juli 2020). Dari 350

9 Aji Sofanudin, 'Minat Masyarakat Terhadap Model Pendidikan Madrasah Di Magelang Dan Demak', Edukasi: Jurnal Penelitian Pendidikan Agama Dan Keagamaan, 2012 <Https://Doi.Org/10.32729/Edukasi.V10i3.170>. 
guru madrasah Aliyah sebanyak 311 guru mengisi angket. Dari jumlah tersebut sebanyak 9 data rusak (tidak digunakan) karena isian tidak lengkap ataupun data kembar/double. Sehingga yang dianalisis sebanyak 302 angket. Dengan menggunakan analisis deskripsi diperoleh gambaran bahwa teacher engagement guru madrasah Aliyah di kabupaten tegal sebesar 90 (rentang 0-100). Hal ini mengindikasikan bahwa sesungguhnya keterlibatan guru madrasah aliyah dalam pembelajaran di kabupaten Tegal tinggi. Artinya, semangat, dedikasi, pengabdian guru madrasah aliyah tidak diragukan dalam kerangka memajukan madrasah. Kompetensi kepribadian guru madrasah aliyah di kabupaten Tegal tergolong baik. Para guru sadar betul akan tanggung jawabnya sebagai seorang pendidik. Pandangan bahwa guru hanya "makan gaji buta" tidak benar. Kewajiban mereka sebagai guru ditunaikan dengan baik, meskipun dengan banyak kendala. Bahkan, guru madrasah siap dan melakukan cara kasbon (berhutang) untuk memenuhi kewajibannya sebagai guru.

Beberapa kendala pembelajaran daring pada madrasah Aliyah di kabupaten Tegal adalah sebagai berikut: (1) Masalah jaringan internet/koneksi internal/sinyal. Masalah tersebut sinyal dipetakan menjadi dua yaitu tidak ada sinyal dan sinya yang tidak stabil (2) Masalah HP atau Laptop. Masalah tersebut dipetakan dari: tidak punya HP atau lapotop, punya HP tapi belum android, punya tetapi tidak cukup jumlah misal satu HP digunakan oleh tiga orang anak/HP milik orang tua, (3) Masalah kuota. Masalah tersebut dipetakan menjadi: tidak mampu beli kuoto ataupun mampu tetapi terbatas (4) masalah siswa, dipetakan menjadi: tidak focus belajar, malas, semangat belajar rendah, malas, bosan, jenuh, sehingga pemahaman/penguasaan terhadap materi rendah/kurang (5) masalah guru, dipetakan menjadi: gagap teknologi, kurang menguasai IT, lebih banyak memberikan penugasan, tidak bisa memantau siswa, kesulitan evaluasi pembelajaran (6) pembelajaran tidak efektif dan efisien, masalah ini dipetakan menjadi: persiapan mengajar lebih ribet, durasi pembelajaran terbatas, berbiaya tinggi, metode pembelajaran monoton, tidak bisa praktikum (7) aturan madrasah berbasis pesantren yaitu tidak boleh membawa/pegang HP.

\section{Nilai Teachers Engagement Guru Laki-laki dan Perempuan}

Sebagian besar guru madrasah aliyah di kabupaten Tegal adalah berjenis kelamin laki-laki. Berdasarkan data seksi pendidikan madrasah kantor kementerian agama kabupaten Tegal diketahui bahwa jumlah guru laki-laki sebanyak 190 guru (54, $28 \%$ ) sementara guru perempuan sebanyak 160 guru $(45,72 \%)$. Sementara jumlah guru laki-laki yang mengisi angket sebanyak 159 (52,64 \%) orang dan guru perempuan yang mengisi angket sebanyak 143 (47,35\%) guru.

Tabel 5 Data Subjek Penelitian

\begin{tabular}{llll}
\hline No & Jenis Kelamin & Data Guru & Guru Pengisi Angket \\
\hline 1 & Laki-laki & $190(54,28 \%)$ & $159(52,65 \%)$ \\
\hline 2 & Perempuan & $160(45,72 \%)$ & $143(47,35 \%)$ \\
\hline Jumlah & $350(100 \%)$ & $302(100 \%)$ \\
\hline
\end{tabular}

Sumber: data diolah, 2020

Berdasarkan tabel 5 tersebut, maka partisipasi guru perempuan yang mengisi angket lebih tinggi $(47,35 \%)$ dibandingkan dengan data real guru perempuan di Kabupaten Tegal (45,72 \%). Dilihat dari perimbangan persentase antara data real guru dengan data pengisi angket sudah berimbang. Pada guru perempuan hanya 17 guru yang tidak mengisi, sementara pada guru laki-laki 
sebanyak 31 guru tidak berpartisipasi. Sementara secara total tingkat partisipasi sebanyak 86, $28 \%$ guru berpartisipasi dalam pengisian angket. Angka ini sangat tinggi, melebihi prasyarat persentase sampel yang hanya $25 \%{ }^{10}$.

Dengan menggunakan analisis SPSS, diperoleh temuan bahwa terdapat perbedaan teachers engagement antara guru laki-laki dan perempuan. Nilai $r_{h}$ sebesar 0,209 lebih kecil daripada nilai $r_{\text {tabel. }}$

\begin{tabular}{l}
\begin{tabular}{|l|r|r|r|}
\hline & Mescriptive Statistics \\
\hline & $\begin{array}{c}\text { Std. } \\
\text { Deviation }\end{array}$ & $\mathrm{N}$ \\
\hline Laki-laki & 4.6230 & .38524 & 159 \\
Perempua & 4.5599 & .39790 & 143 \\
$\mathrm{n}$ & Correlations
\end{tabular} \\
\hline
\end{tabular}

\begin{tabular}{|c|c|c|c|}
\hline & & Laki-laki & $\begin{array}{c}\text { Perempua } \\
\mathrm{n}\end{array}$ \\
\hline \multirow{5}{*}{ Laki-laki } & Pearson Correlation & 1 & $.209^{*}$ \\
\hline & Sig. (2-tailed) & & .012 \\
\hline & $\begin{array}{l}\text { Sum of Squares and } \\
\text { Cross-products }\end{array}$ & 23.449 & 4.645 \\
\hline & Covariance & 148 & .033 \\
\hline & $\begin{array}{l}\mathrm{N} \\
\text { Pearson Correlation }\end{array}$ & $\begin{array}{c}159 \\
.209^{*}\end{array}$ & $\begin{array}{r}143 \\
1\end{array}$ \\
\hline \multirow{4}{*}{$\begin{array}{l}\text { Perempua } \\
\mathrm{n}\end{array}$} & Sig. (2-tailed) & .012 & \\
\hline & $\begin{array}{l}\text { Sum of Squares and } \\
\text { Cross-products }\end{array}$ & 4.645 & 22.482 \\
\hline & Covariance & .033 & 158 \\
\hline & $\mathrm{N}$ & 143 & 143 \\
\hline
\end{tabular}

Laki-laki dan perempuan secara alamiah memang berbeda. Temuan penelitian ini sejalan dengan penelitian sebelumnya bahwa terdapat perbedaan nilai kerja antara laki-laki dan perempuan pada madrasah aliyah berbasis pesantren di Ponorogo (Rahmawati, dkk. 2020).

Temuan penelitian Permatasari dan Hadi ${ }^{11}$ terhadap para guru honorer SMA dan SMK di Surabaya menunjukkan bahwa ada korelasi negatif antara job insecurity dengan work engagement. Artinya, meskipun berstatus sebagai guru honorer para guru memiliki work engagement yang tinggi. Menurut Schufelli dkk ${ }^{12}$ work engagement merupakan keadaan mental positif dimana kondisi pikiran seseorang ketika bekerja ditandai oleh penuhnya vigor, dedikasi, dan absorption. Vigor merupakan tingkat energi yang tinggi dan resiliensi mental pada saat bekerja yang dimiliki oleh seseorang. Dedikasi merupakan ketahanan dalam bekerja yang dimiliki oleh seseorang meliputi antusiasme dan menyukai tantangan. Sedangkan absorption merupakan penyerapan seseorang ketika bekerja bekerja ditandai dengan konsentrasi penuh, bangga dan perasaan bahagian dalam bekerja.

${ }^{10}$ Suharsimi. Arikunto, Prosedur Penelitian Pendekatan Praktik Edisi Revisi VI., Rineka Cipta, 2010 .

${ }^{11}$ Finsa Permatasari Dan Cholicul Hadi, 'Hubungan Antara Job Insecurity (Ketidakamanan Kerja) Dengan Work Engagement (Keterikatan Kerja) Pada Guru Honorer Sma Negeri Di Surabaya', Jurnal Psikologi Industri Dan Organisasi, 7 (2018), 43-55.

12 Wilmar B. Schaufeli, Arnold B. Bakker, and Marisa Salanova, 'The Measurement of Work Engagement with a Short Questionnaire: A Cross-National Study', Educational and Psychological Measurement, 2006 <https://doi.org/10.1177/0013164405282471>. 
Dengan menggunakan analisis SPSS diperoleh data bahwa ada perbedaan nilai teachers engagement antara guru laki-laki dan guru perempuan. Guru laki-laki memiliki keterlibatan mengajar yang lebih intens dibandingkan dengan guru perempuan. Semangat, dedikasi, dan keterlibatan guru laki-laki dalam mengajar lebih tinggi dibandingkan dengan guru perempuan.

\section{Teachers Engagement Guru Tersertifikasi dan Belum Sertifikasi}

Berdasarkan data seksi pendidikan madrasah kantor kementerian agama kabupaten Tegal diketahui bahwa jumlah guru setifikasi sebanyak 155 guru (44, $3 \%$ ) sementara guru yang belum tersertifikasi sejumlah 195 guru $(55,7 \%)$. Sementara jumlah guru sertifikasi yang mengisi angket sebanyak $170(56,3 \%)$ orang dan guru belum sertifikasi sebanyak $132(43,7 \%)$ guru.

Tabel 6 Data Guru Sertifikasi

\begin{tabular}{llll}
\hline No & Status Guru & Data Guru & Guru Pengisi Angket \\
\hline 1 & Guru Sertifikasi & $155(44,3 \%)$ & $170(56,3 \%)$ \\
\hline 2 & Guru Belum Sertifikasi & $195(55,7 \%)$ & $132(43,7 \%)$ \\
\hline Jumlah & $350(100 \%)$ & $302(100 \%)$ \\
\hline
\end{tabular}

Sumber: data diolah, 2020

Dari data tersebut diketahui bahwa partisipasi guru sertifikasi lebih tinggi (56, $3 \%$ ) dibandingkan dengan existing guru (44, $3 \%$ ). Data ini bisa menjadi pembanding bahwa guru sertifikasi memiliki teacher engagement dibandingkan dengan guru non sertifikasi. Data ini sejalan dengan temuan penelitian yang dilakukan terhadap guru di Denpasar ${ }^{13}$. Guru sertifikasi memiliki nilai rerata teachers engagement yang lebih tinggi dibandingkan dengan guru yang belum tersertifikasi.

Dengan menggunakan analisis SPSS, diperoleh temuan bahwa secara statistic tidak terdapat perbedaan teachers engagement antara guru sertifikasi dan belum sertifikasi di mana nilai $\mathrm{r}_{\mathrm{h}}$ sebesar $-0,001$.

Descriptive Statistics

\begin{tabular}{|l|r|r|r|}
\hline & \multicolumn{1}{|c|}{ Mean } & Std. Deviation & \multicolumn{1}{c|}{ N } \\
\hline Sertifikasi & 4.7386 & .25113 & 132 \\
Belum Sertifikasi & 4.4802 & .44196 & 170 \\
\hline
\end{tabular}

\begin{tabular}{|c|c|c|c|}
\hline & & Sertifikasi & $\begin{array}{c}\text { Belum } \\
\text { Sertifikasi }\end{array}$ \\
\hline \multirow{5}{*}{ Sertifikasi } & Pearson Correlation & 1 & -.001 \\
\hline & Sig. (2-tailed) & & .995 \\
\hline & $\begin{array}{l}\text { Sum of Squares and Cross- } \\
\text { products }\end{array}$ & 8.262 & -.008 \\
\hline & Covariance & .063 & .000 \\
\hline & $\begin{array}{l}\mathrm{N} \\
\text { Pearson Correlation }\end{array}$ & $\begin{array}{r}132 \\
-.001\end{array}$ & $\begin{array}{r}132 \\
1\end{array}$ \\
\hline \multirow{4}{*}{ Belum Sertifikasi } & Sig. (2-tailed) & .995 & \\
\hline & $\begin{array}{l}\text { Sum of Squares and Cross- } \\
\text { products }\end{array}$ & -.008 & 33.011 \\
\hline & Covariance & .000 & .195 \\
\hline & $\mathrm{N}$ & 132 & 170 \\
\hline
\end{tabular}

${ }^{13}$ Gede Andi Aditya And I Nyoman Adiputra, 'Perbedaan Skor Work Engagement Pada Guru Yang Bersertifikasi Dengan Guru Yang Belum Bersertifikasi Di Smp Negeri Se-Kecamatan Denpasar Utara', Jurnal Ergonomi Indonesia (The Indonesian Journal Of Ergonomic), 2015 <Https://Doi.Org/10.24843/Jei.2015.V01.I02.P03>. 
Cara meningkatkan teachers engagement guru madrasah aliyah di kabupaten Tegal sangat tergantung kondisi masing-masing madrasah. Selain dipengaruhi pribadi masing-masing guru yang bersangkutan. Setiap orang memiliki kepribadian yang berbeda-beda. Dengan kepribadian yang berbeda-beda diperlukan treatment yang berbeda pula. Temuan penelitian terhadap guru di Denpasar menunjukkan bahwa terdapat perbedaan rerata skor work engagement antara guru yang bersertifikasi dengan guru yang belum bersertifikasi. Skor work engagement guru bersertifikasi lebih tinggi daripada guru yang belum bersertifikasi.

Rasa tanggung jawab guru madrasah luar biasa. Ada guru madrasah bahkan sampai rela melaksanakan kas bon untuk membiaya pembelian kuota internet. Rasa tanggung jawab guru madrasah dalam melakukan tugas pembelajaran tergolong tinggi. Problem pembelajaran daring salah satunya bisa diatasi dengan adanya rasa tanggung jawab guru sebagai pendidik. Di tengahtengah kesulitan guru dalam melakukan pembelajaran guru madrasah swasta memiliki ruhul jihad, berjuang melalui pendidikan dengan sungguh-sungguh.

Kementerian Pendidikan dan Kebudayaan (Kemendikbud) mengeluarkan kebijakan populis untuk menunjang proses pembelajaran jarak jauh (PJJ) pada masa pandemi Covid-19. Kebijakan tersebut berupa subsidi kuota internet untuk siswa, guru, mahasiswa, dan dosen. Anggaran subsidi fantastis Rp 7,2 triliun. Rencananya diberikan empat kali dari September sampai Desember 2020. Kuota 35 GB per bulan bagi siswa, 42 GB bagi guru, dan 50 GB bagi dosen serta mahasiswa.

Catatan lain adalah bahwa dari sisi jumlah murid atau penerimaan peserta didik baru (PPDB), kondisi madrasah di kabupaten tegal cukup memprihatinkan. Berdasarkan "obrolan" terjadi rebutan siswa antar berbagai madrasah aliyah sederajat. Banyak faktor, di antaranya adalah karena menjamurnya satuan Pendidikan di kabupaten Tegal (SMA/MA/SMK). Rasio jumlah SMA sederajat dengan jumlah lulusan SMP sederajat kecil. Oleh karena itu, di lapangan yang terjadi adalah adanya fenomena "rebutan murid". Banyak sekolah menawarkan berbagai program: beasiswa, gratis SIM C, baju seragam dan lain-lain dalam rangka "menggaet" siswanya.

\section{SIMPULAN}

Temuan penelitian menunjukkan bahwa teachers engagement guru madrasah aliyah terdiri atas lima aspek yaitu (1) vigor, (2) dedication, (3) absorpsion, (4) job satisfaction, dan (5) quitting intention. Berdasarkan kelima aspek tersebut diketahui bahwa nilai teachers engagement guru madrasah aliyah di Kabupaten Tegal sebanyak 87, $1 \%$ berkategori tinggi, 12, $9 \%$ berkategori sedang dan tidak ada yang berkategori rendah. Mean empirik pada setiap aspek adalah sebagai berikut: (1) vigor 13,6 (2) dedication 14,05 (3) absorpsion 1378 (4) job satisfaction 13,76 dan (5) quitting intention 4,29. Berdasarkan hal tersebut diketahui bahwa guru Madrasah Aliyah di Kabupaten Tegal memiliki dedikasi yang sangat tinggi dibandingkan aspek yang lain.

Dengan menggunakan lima aspek tersebut, diketahui bahwa ada perbedaan teacher engagement antara guru laki-laki dan perempuan. Guru laki-laki memiliki nilai teacher engagement lebih tinggi daripada guru perempuan. Mean teacher engagement guru laki-laki sebesar 4,62 sementara guru perempuan sebesar 4,55. Nilai $r_{h}$ sebesar 0,209 lebih besar daripada nilai $r_{\text {tabel }}$ baik pada signifikansi $5 \%$ ataupun $1 \%$. Ini menunjukkan bahwa ada perbedaan nilai teacher engagement antara laki-laki dan perempuan.

Sementara mean guru tersertifikasi $(4,73)$ lebih tinggi daripada guru belum tersertifikasi $(4,48)$. Nilai $r_{h}$ sebesar -0,001 menunjukkan bahwa tidak ada perbedaan nilai teacher engagement antara guru sertifikasi dengan guru belum tersertifikasi pada Madrasah Aliyah di Kabupaten Tegal. Berdasarkan uji SPSS tersebut, diketahui bahwa meskipun nilai mean teachers engagement guru tersertifikasi lebih tinggi daripada yang belum tersertifikasi namun secara statistik tidak ada perbedaan antara keduanya. 


\section{DAFTAR PUSTAKA}

Aditya, Gede Andi, And I Nyoman Adiputra, 'Perbedaan Skor Work Engagement Pada Guru Yang Bersertifikasi Dengan Guru Yang Belum Bersertifikasi Di Smp Negeri Se-Kecamatan Denpasar Utara', Jurnal Ergonomi Indonesia (The Indonesian Journal Of Ergonomic), 2015 <Https://Doi.Org/10.24843/Jei.2015.V01.I02.P03>

Amirudin, Noor, 'Problematika Pembelajaran Pendidikan Agama Islam Di Era Digital', Prosiding Seminar Nasional Pai Dengan Pendekatan Multidisipliner, 2019

Arikunto, Suharsimi., Prosedur Penelitian Pendekatan Praktik Edisi Revisi Vi., Rineka Cipta, 2010

Darmawan, Cecep “Kedaulatan Digital” Opini Republika, 3 September 2020

Hadi, Finsa Permatasari Dan Cholicul, 'Hubungan Antara Job Insecurity (Ketidakamanan Kerja) Dengan Work Engagement (Keterikatan Kerja) Pada Guru Honorer Sma Negeri Di Surabaya', Jurnal Psikologi Industri Dan Organisasi, 7 (2018), 43-55

Iswanto, Agus Dkk., "Survei Pembelajaran Jarak Jauh Masa Covid" Balai Penelitian Dan Pengembangan Agama Semarang, 2020 <Https://Doi.Org/10.13140/Rg.2.2.30082.71366>

Klassen, Robert M., Said Aldhafri, Caroline F. Mansfield, Edy Purwanto, Angela F.Y. Siu, Marina W. Wong, And Others, 'Teachers Engagement At Work: An International Validation Study', Journal Of Experimental Education, 2012 <Https://Doi.Org/10.1080/00220973.2012.678409>

Klassen, Robert M., Sündüs Yerdelen, And Tracy L Durksen, 'Measuring Teacher Engagement: Development Of The Engaged Teachers Scale (Ets)', Frontline Learning Research, 2013 $<$ Https://Doi.Org/10.14786/Flr.V1i2.44>

Murtadlo, Dkk. "Survei Pembelajaran Jarak Jauh" Puslitbang Pendidikan Agama Dan Keagamaan, 2020

Schaufeli, Wilmar B., Arnold B. Bakker, And Marisa Salanova, 'The Measurement Of Work Engagement With A Short Questionnaire: A Cross-National Study', Educational And Psychological Measurement, 2006 <Https://Doi.Org/10.1177/0013164405282471>

Siaran Pers Kementerian Pendidikan Dan Kebudayaan, 15 Juni 2020

Sofanudin, Aji, 'Minat Masyarakat Terhadap Model Pendidikan Madrasah Di Magelang Dan Demak', Edukasi: Jurnal Penelitian Pendidikan Agama Dan Keagamaan, 2012 $<$ Https://Doi.Org/10.32729/Edukasi.V10i3.170. 